\title{
EDITORIAL: MINING IN A SUSTAINABLE WORLD
}

Humanity has reaped great benefits from mining. Over the millennia that humans have practiced mining there have been many obvious improvements in mining's environmental and social impacts. However, some aspects of mining still involve an element of ecological violence ${ }^{1}$ and, in Australia, there is a growing amount of conflict concerned with mining. These two related issues - 'ecological violence' and 'conflict' were explored at the 'Mining in a Sustainable World' conference on 13 to 15 October 2013 at the University of New England campus in Armidale, Australia. The conference was a joint initiative of the discipline of Peace Studies within the University of New England's School of Humanities, and the Australian Centre for Agriculture and Law. Specifically, conference delegates were interested in exploring the work being done to reduce ecological violence and conflict. Articles in this special edition of the International Journal of Rural Law and Policy arose from that conference. This editorial provides an overview of the rationale for the conference and the issues explored.

In Australia since the 1980 s, there have been almost constant protests against mines or planned mining projects, beginning with blockades of the Honeymoon, Beverley and Olympic Dam uranium mines in South Australia. The 1998 campaign against the proposed uranium mine at Jabiluka in the Northern Territory was an international one - with actions in Japan, Canada, Germany, Japan, the Netherlands, Britain, South Korea and the US - and a national one - focussing on Westpac Bank branches in cities around Australia. There were high school walkouts involving 14000 students, and a blockade at Jabiluka involving up to 5000 people, including the Mirrar traditional owners - six hundred people were arrested as a result of the protests.

The proposed $\$ 40$ billion gas hub at James Price Point in Western Australia was opposed through court actions and a blockade, beginning in 2011, that was met by $\$ 1$ million police action, 'Operation Archon'. As with Jabiluka, the project did not eventuate. More recently, blockades have been organised to protest against the extraction of coal seam gas in northern New South Wales. These have been complemented by public education and corporate campaigns promoting boycotts and divestments. In March 2014, an estimated 3000 people blockaded a proposed site for unconventional gas extraction at Bentley near Lismore. A planned deployment of 1000 police to the region was only aborted after intense lobbying led to the state government revoking the company's licence and referring the matter to the Independent Commission Against Corruption. The company is now suing the state government.

To give a final example, there is ongoing protest against a proposed coalmine at Maules Creek near Narrabri (north west NSW), which involves partial clearing of the Leard State Forest. At peak protest times, there are 200 police ensconced in Narrabri, and a police roadblock in place. Those wishing to pass through the roadblock can be questioned and searched. There has been an average of two arrests per week; occasionally there are significantly more arrests, including one instance when sixty people were arrested. In total, there have now been 220 arrests for nonviolent civil disobedience. The broad nature of community opposition is demonstrated by the fact that those arrested include a blind 92-year-old veteran of the Kokoda trail, a former public prosecutor, doctors and other health professionals, farmers, 'grey nomads', academics, ecologists and students. All of these conflicts involve high financial and social costs.

Complex social and environmental justice issues are involved in these conflicts, with environmental and planning laws appearing to favour the consumption of natural resources. However, mining developers complain that they are bearing heavy costs. They argue they lack the certainty needed for long-term investments and that the mining industry is already well regulated, undertakes lengthy and detailed approval processes, employs many people and creates spin-off industries. In spite of doing nothing illegal, industry spokespeople point out that they have been bullied and shouted down at public forums.

Industry opponents claim that governments have been captured by a wealthy, entrenched industry. They point to the massive industry public relations campaign, which outspent the government's ten-to-one,

\footnotetext{
1 Dennis Soron defines 'ecological violence' as 'the callous misuse and despoliation of nature itself (that can rebound) back upon (humanity) as structural violence, destroying lives and livelihoods, amplifying existing conflicts and inequalities, and exposing countless people to severe storms, floods, drought, fire, disease, displacement, and chronic food and water insecurity' (Dennis Soron, Cruel Weather: Natural Disasters and Structural Violence [2007] (14). Transformations <http://www.transformationsjournal.org/journal/issue_14/article_01.shtml>.
} 
against the former Australian Labor Government's proposed mining tax. The Prime Minister was removed from the leadership shortly afterwards and the tax was then considerably watered down. Communities claim that poor regulatory practices have been followed - examples include: the Leard State Forest offset plan, which has been widely criticised; and the Queensland coal seam gas project approvals in 2010. In the latter example, the whistleblower, Simone Marsh, who was a senior environmental specialist with the Queensland Government, claimed that coal seam gas project approvals in 2010 breached Queensland's Environmental Protection Act 1994. She asserted that projects were approved: in spite of inadequate information and too little time to investigate; and under pressure to accede to demands to push through projects with questionable environmental safeguards. These claims were not upheld by a Crime and Misconduct Commission inquiry. Nevertheless, activists argue, decisions are too often made in secret, without adequate community input.

The 'Mining in a Sustainable World' conference organisers were interested in bringing a diverse group of people with expertise and interest in mining into a well-moderated and safe forum to explore areas of agreement and disagreement, share information, and work towards possible conflict transformation.

The aim was to generate open, high-level and interdisciplinary discussion of contentious issues. Experts in a variety of fields were invited, while members of community groups were also given the opportunity to submit proposals to present papers. Many mining companies and representative bodies were invited but few responded to the invitations, and those who did declined to attend. There were criticisms of the conference as not having a sufficient balance of views, but this was not able to be avoided by the organisers. The editors of the journal acknowledge that, as a result, the collection in this edition does not fully expose the extractive industry perspectives that would be desirable for a complete examination of the issues, and for the type of engaged problem solving that is needed to cope with the complex issues.

This special edition of the International Journal of Rural Law and Policy includes the program of the conference, as well as the biographies of speakers and abstracts of papers from the conference. Papers presented at the conference explored domestic, international, political, social and scientific issues. A number of versions of the presentations were peer reviewed and included in this special edition. Also included in this edition is a 'commentaries' section in which short papers (not peer reviewed) submitted by presenters are reproduced.

Papers included from the conference in this edition span a diverse field of interests and disciplines, including: sustainability of open-cut coal mining in the Hunter Valley region of Australia (Cottle and Keys); analysis of a carbon tax on the resources sector (Meng, Siriwardana and McNeil)l; the rationale and evolution of the Australian movement against uranium mining (Branagan); tracking the current mining boom in Australia and identifying indicators of cumulative socioeconomic impacts via action research (Rifkin, Uhlmann, Everingham and May); the socio-economic impacts of mining and mine closure, and how mine life cycle planning and enduring value needs to be better planned for remote communities (Robertson and Blackwell). Equally, there are a diverse range of international inter-disciplinary papers including issues affecting better management of mining revenues and distribution of benefits within Papua New Guinea (Polume-Kiele); case studies of Antioquia and Risaralda, two mining districts of Colombia in South America where the sustainable livelihood approach meets the challenge of counter-narratives of economic growth and environmental conservation (see commentaries - Buitrago-Franco and Chatterji); the history and effects of oil exploration and laws in the Niger Delta and the rise of militants and terrorists in the area, with suggestions for peaceful resolutions of the land use conflicts (Madubuko).

We thank all those who attended the Conference and contributed to this journal edition. The Conference was designed to offer a safe space for researchers, community organisations, politicians, industry groups, members of the community and others to come together to talk about how mining could be achieved in a sustainable world. We encourage you to read the peer-reviewed papers of this special edition and also view the conference program and abstracts, which demonstrate the diverse and prolific conversations that occurred over the three-day conference.

Marty Branagan

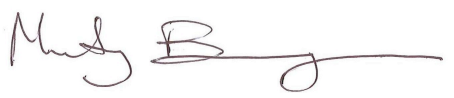

Jacqueline Williams

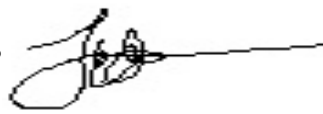

Amanda Kennedy

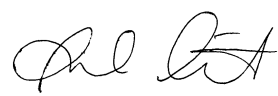

